Volume 7 Nomor 3 Tahun 2019

\title{
Penerapan Pendekatan Paikem untuk Meningkatkan Pembelajaran Matematika Tentang Pengukuran Sudut pada Siswa Kelas IV SD Negeri 3 Purwodadi Tahun Ajaran 2018/2019
}

\author{
Mauliddhina Imas $\mathbf{P}^{1}$, Wahyudi ${ }^{2}$, M. Chamdani ${ }^{3}$ \\ 1,2,3Universitas Sebelas Maret
}

\section{Article History}

accepted 01/10/2019

approved 01/11/2019

published 01/12/2019

\begin{abstract}
This study aimed to improve Mathematics learning about angular measurement in grade IV students through the application of the PAIKEM approach. This research was collaborative classroom action research with three cycles. The data used were quantitative data and qualitative data. The subjects of this study were teacher and grade IV students in SDN 3 Purwodadi in Academic Year 2018/2019. The data used were qualitative data in the form of observation and interviews about implementation PAIKEM approach and quantitative data in the form of the value of learning evaluation. Data collection techniques used observation, interviews, tests, and documentation. Data validity used sources and technique triangulation. Data analysis included data reduction, data presentation, and conclusion drawing. The result of this study is that the PAIKEM approach could improve Mathematics learning about angular measurement in grade IV students of SDN 3 Purwodadi in Academic Year 2018/2019.
\end{abstract}

Keywords: PAIKEM approach, mathematics, angle measurement

\begin{abstract}
Abstrak
Penelitian ini bertujuan untuk meningkatkan pembelajaran Matematika tentang pengukuran sudut pada siswa kelas IV melalui penerapan pendekatan PAIKEM. Jenis Jenis penelitian ini adalah penelitian tindakan kelas kolaboratif dengan tiga siklus. Data yang digunakan adalah data kuantitatif dan data kualitatif. Subjek penelitian ini adalah guru dan siswa kelas IV di sekolah dasar negeri 3 Purwodadi tahun ajaran 2018/2019. Data yang digunakan adalah data kualitatif yang berupa hasil observasi dan wawancara tentang penerapan pendekatan PAIKEM dan data kuantitatif berupa nilai tes evaluasi. Teknik pengumpulan data yang digunakan adalah observasi, wawancara, tes, dan dokumentasi. Validitas data menggunakan triangulasi teknik dan sumber. Analisis data meliputi reduksi data, penyajian data, dan penarikan kesimpulan. Hasil penelitian ini adalah pendekatan PAIKEM dapat meningkatkan pembelajaran Matematika tentang pengukuran sudut pada siswa kelas IV sekolah dasar negeri 3 Purwodadi tahun ajaran 2018/2019.
\end{abstract}

Kata Kunci: pendekatan PAIKEM, matematika, pengukuran sudut 


\section{PENDAHULUAN}

Pendidikan pada abad ke-21 tidak terlepas dari pengaruh teknologi informasi dan peran pendidik dalam proses pembelajaran. Sebagian besar pembelajaran saat ini menerapan kurikulum 2013 terintegratif berbasis saintifik dengan menanamkan nilai pendidikan karakter dan menuntut siswa agar memiliki keterampilan, pengetahuan, kemampuan pada bidang teknologi, media, informasi dan inovasi dalam pembelajaran. Pendidikan menjadi semakin penting untuk menjamin siswa memiliki skills atau kemampuan yang berguna bagi kehidupan siswa di masa yang akan datang (Arifin, 2017: 93). Proses belajar siswa akan lebih optimal jika siswa mempelajari sesuatu secara langsung. Hal ini mendorong siswa mengaitkan materi yang sudah didapatkannya dengan kehidupan sehari-hari, sehingga membantu siswa memecahkan masalah-masalah dalam kehidupan yang berhubungan dengan Matematika.

Siswa harus aktif menemukan sendiri berbagai pengetahuan yang diperlukannya. Tujuan pembelajaran Matematika adalah untuk melatih cara berpikir sistematis, logis, kritis, kreatif dan konsisten (Wahyudi, 2015: 68).

Data yang diperoleh dari guru kelas IV SD Negeri 3 Purwodadi masih tergolong rendah, dimana hasil belajar Matematika siswa kelas IV SD Negeri 3 Purwodadi pada penilaian tengah semester ganjil (PTS 1) tahun ajaran 2018/2019 terdapat 16 atau $62 \%$ siswa yang hasilnya kurang dari Kriteria Ketuntasan Minimal (KKM) yaitu 61 dan hanya 10 atau $38 \%$ siswa yang sudah mencapai batas ketuntasan belajar.

Berdasarkan observasi pada hari Sabtu, 24 November 2018 dalam pembelajaran Matematika di kelas IV SD Negeri 3 Purwodadi, diperoleh informasi bahwa: (1) siswa pasif dalam pembelajaran, misalnya siswa belum berani bertanya soal pembelajaran, (2) proses pembelajaran masih menggunakan metode konvensional dan belum menerapkan pendekatan yang inovatif, (3) siswa belum difasilitasi untuk terlibat secara langsung dalam proses pembelajaran sehingga siswa belum tertarik dalam pembelajaran, hal ini dapat dilihat dari beberapa siswa berbicara dengan temannya saat pembelajaran.

Dari permasalahan yang ditemukan saat observasi menunjukan aktivitas dan hasil belajar siswa masih rendah. Hal tersebut menandakan bahwa adanya permasalahan yang perlu dicari solusi untuk memecahakan permasalahan tersebut. Mengingat guru mempunyai peranan besar dalam proses pembelajaran, maka guru diharuskan untuk selalu proaktif dan responsif terhadap hal-hal yang terjadi di dalam kelas maupun di lingkungan siswa. Perlu adanya inovasi terhadap pendekatan yang digunakan saat pembelajaran untuk meningkatkan aktivitas siswa sehingga dapat meningkatkan hasil belajar siswa. Menurut Siregar, Wardani, \& Hatika (2017: 745) pendekatan Pembelajaran Aktif, Inovatif, Kreatif, Efektif, dan Menyenangkan (PAIKEM) dianggap yang relevan karena dapat mengakomondasi tuntutan perkembangan seluruh aspek dalam diri anak, seperti aspek kognitif, afektif, dan psikomotor.

Berdasarkan hasil dari wawancara dengan guru kelas IV SD Negeri 3 Purwodadi, materi yang dianggap masih sulit untuk dipahami oleh anak adalah materi tentang pengukuran sudut. Berdasarkan masalah tersebut, maka dalam pembelajaran Matematika perlu adanya perbaikan, seperti menciptakan suasana kelas yang menyenangkan agar siswa bersemangat dalam mengikuti proses pembelajaran. Peneliti memilih pendekatan PAIKEM untuk menumbuhkan minat dan bakat siswa kelas IV SD Negeri 3 Purwodadi dalam mempelajari Matematika secara aktif, inovatif, kreatif, efektif, dan menyenangkan sehingga dapat meningkatkan pembelajaran Matematika.

Berkaitan dengan uraian di atas, peneliti tertarik untuk mengadakan Penelitian Tindakan Kelas (PTK) yang berkolaborasi dengan guru kelas IV guna meningkatkan pembelajaran Matematika tentang pengukuran sudut di kelas IV SD Negeri 3 Purwodadi dengan judul "Penerapan Pendekatan PAIKEM untuk Meningkatkan 
Pembelajaran Matematika tentang Pengukuran Sudut pada Siswa Kelas IV SD Negeri 3 Purwodadi Tahun Ajaran 2018/2019."

\section{METODE PENELITIAN}

Penelitian ini merupakan penelitian tindakan kelas (PTK) kolaboratif. Prosedur penelitian yang digunakan adalah modifikasi dari Arikunto (2013: 137) yang setiap siklusnya terdiri dari tahap yaitu perencanaan, pelaksanaan, pengamatan, dan refleksi. Subjek dalam penelitian ini adalah siswa kelas IV SD Negeri 3 Purwodadi yang berjumlah 26 siswa. Data yang digunakan adalah data kuantitatif berupa nilai tes evaluasi dan data kualitatif berupa hasil observasi dan wawancara tentang penerapan pendekatan PAIKEM. Teknik pengumpulan data menggunakan observasi, wawancara, tes, dan dokumentasi. Validitas data menggunakan triangulasi teknik dan sumber. Analisis data meliputi reduksi data, penyajian data, dan penarikan kesimpulan (Sugiyono, 2015: 337-345). Indikator kinerja penelitian ini adalah penerapan pendekatan PAIKEM dalam pembelajaran melalui observasi dan wawancara sebesar $85 \%$ dan peningkatan pembelajaran Matematika dengan jumlah siswa tuntas di atas $85 \%$ dengan KKM 70.

\section{HASIL DAN PEMBAHASAN}

Penelitian ini dilaksanakan selama tiga siklus dan menerapkan pendekatan PAIKEM dengan karakteristik yaitu: (1) aktif, (2) inovatif, (3) kreatif, (4) efektif, (5) menyenangkan. Karakteristik yang digunakan oleh peneliti mengacu pendapat yang dikemukakan oleh Jauhar (2011: 156-164), dan Ahmadi dan Amri (2012: 141-142) yang kemudian disimpulkan menjadi karakteristik yang telah disebutkan di atas.

Berdasarkan kegiatan observasi terhadap guru, persentase rata-rata pada siklus $\mathrm{I}=86,58 \%$, siklus $\mathrm{II}=89,78 \%$, dan siklus $\mathrm{III}=93,21 \%$. Persentase rata-rata observasi terhadap siswa pada siklus I $=86,43 \%$, siklus $\mathrm{II}=88,66 \%$, dan siklus $\mathrm{III}=92,77 \%$. Berdasarkan hasil tersebut dapat dilihat bahwa persentase observasi guru dan siswa sudah mencapai $85 \%$. Peneliti melakukan wawancara dengan guru dan siswa kelas IV untuk memperkuat hasil penelitian. Berdasarkan wawancara pada siklus I didapatkan informasi bahwa guru masih mengalami kesulitan pada karakteristik aktif yaitu pada saat pertanyaan dan pemberian tanggapan pada saat tanya jawab. Guru belum mampu memberikan motivasi yang tepat untuk merangsang keaktifan siswa. Berdasarkan hasil wawancara dengan siswa didapatkan hasil bahwa siswa merasa lebih bersemangat jika selama pembelajaran menggunakan video dan permainan cek konsentrasi. Kesulitan yang dihadapi siswa yaitu pada karakteristik aktif, siswa belum mau mengajukan pertanyaan dan memberi tanggapan. Wawancara pada siklus II didapatkan informasi bahwa guru sudah memberikan motivasi siswa untuk aktif bertanya dan memberikan tanggapan tetapi tanggapan siswa saat diskusi belum semuanya tepat karena masih ada siswa yang belum paham cara pemberian tanggapan yang tepat. Berdasarkan wawancara dengan siswa didapatkan hasil bahwa siswa sudah mulai berani presentasi hasil diskusi di depan siswa lain dan siswa sudah mulai berani bertanya serta menyampaikan tanggapannya di kelas tetapi terkadang siswa kurang tepat saat memberikan tanggapan karena belum menguasai materi diskusi. Wawancara pada siklus III didaptkan informasi bahwa guru sudah membimbing siswa menganalisis soal latihan, dan memberikan contoh tanggapan yang benar, dan berdasarkan wawancara dengan siswa didapatkan hasil bahwa sebagian sebagian siswa sudah aktif bertanya serta menyampaikan tanggapannya di kelas tetapi masih ada siswa yang menyampaikan pendapatnya belum percaya diri.

Penilaian pengetahuan pada pembelajaran Matematika tentang pengukuran sudut diukur dengan tes evaluasi setelah pembelajaran. Penilaian evaluasi pada pembelajaran Matematika didaptkan hasil bahwa persentase siswa yang tuntas pada pertemuan $1=88,46 \%$. Pada pertemuan $2=88,46 \%$. Persentase rata-rata siswa yang 
tuntas pada siklus I $=88,46 \%$. Dapat disimpulkan dari data tersebut terjadi peningkatan hasil belajar Matematika. Pada siklus II didapatkan hasil bahwa pertemuan 1 persentase siswa yang tuntas $=92,31 \%$. Pada pertemuan 2 persentase siswa yang tuntas $=96,15 \%$. Persentase rata-rata siswa yang tuntas pada siklus II = $94,23 \%$. Dapat disimpulkan dari data tersebut terjadi peningkatan jumlah siswa yang tuntas evaluasi sebesar $5,77 \%$ dari siklus I ke siklus II. Pada siklus III didapatkan hasil bahwa pada pertemua 1 persentase siswa yang tuntas $=96,15 \%$. Dapat disimpulkan dari data tersebut terjadi peningkatan jumlah siswa yang tuntas evaluasi sebesar $1,92 \%$ dari siklus II ke siklus III.

Berdasarkan uraian di atas dapat disimpulkan bahwa indikator penelitian sebesar $85 \%$ dapat tercapai dan terjadi peningkatan hasil belajar Matematika yang menerapkan pendekatan PAIKEM. Hal ini sejalan dengan penelitian yang dilakukan Siregar, Wardani \& Hatika (2017: 744). bahwa pembelajaran dengan menggunakan pendekatan PAIKEM dapat meningkatkan hasil belajar. Pencapaian indikator penelitian sebesar $85 \%$ pada siklus I, II, dan III dipengaruhi oleh faktor eksternal khususnya faktor lingkungan. Menurut Hapnita dkk (2018: 2175) lingkungan sekolah merupakan salah satu faktor eksternal yang dapat mempengaruhi hasil belajar siswa. Menurut Muhibbin (Saputra, Laksono, \& Rina, 2018: 45) lingkungan sosial sekolah seperti para guru, staff administrasi, dan teman-teman sekelas yang dapat mempengaruhi semangat belajar siswa. Semakin baik lingkungan sekolah maka, semakin mendorong siswa untuk lebih giat belajar sehingga mampu meningkatkan hasil belajar. Lingkungan SD Negeri 3 Purwodadi dapat dikatakan sebagai lingkungan sekolah yang baik.

\section{SIMPULAN}

Penerapan pendekatan PAIKEM dalam peningkatan pembelajaran Matematika tentang Pengukuran Sudut pada siswa kelas IV SD Negeri 3 Purwodadi tahun ajaran 2018/2019 dilaksanakan dengan karakteristik: (1) aktif, (2) inovatif, (3) kreatif, (4) efektif, (5) menyenangkan. Penerapan Pendekatan PAIKEM dapat meningkatkan hasil pembelajaran Matematika tentang pengukuran sudut pada siswa kelas IV SD Negeri 3 Purwodadi tahun ajaran 2018/2019. Hal ini dapat dilihat dari persentase rata-rata siswa yang tuntas pada penilaian evaluasi siklus I $=88,46 \%$, siklus II $=94,23 \%$, dan siklus III $=96,15 \%$.

\section{DAFTAR PUSTAKA}

Ahmadi, I,K. dan Amri, S. (2012). Paikem Gembrot. Jakarta: PT Prestasi Pustakaraya.

Arifin, Z. (2017). Mengembangkan Instrumen Pengukur Critical Thinking Skills Siswa pada Pembelajaran Matematika Abad 21. Jurnal Theorems (The Original Research Of Mathematics), 1 (2). 92-100.

Arikunto, S. (2013). Prosedur Penelitian Suatu Pendekatan Praktik. Jakarta: Rineka Cipta.

Hapnita, W. (2018). Faktor Internal dan Eksternal yang Dominan Mempengaruhi Hasil Belajar Menggambar Dengan Perangkat Lunak Siswa Kelas XI Teknik Gambar Bangunan SMK N 1 Padang Tahun 2016/2017. CIVED, 5(1).

Jauhar, Muhammad. (2011). Implikasi Paikem dari Behavioristik Sampai Konstruktivistik. Jakarta: Prestasi Pustaka

Saputra, R. R., Laksono, H., \& Rina, H. (2018). Pengaruh Motivasi Belajar Terhadap Prestasi Belajar Siswa Kelas VII Mts Miftahul Ulum Lampung Barat (Studi Kasus pada Mata Pelajaran Bahasa Arab). JPGMI (Jurnal Pendidikan Guru Madrasah Ibtidaiyah Al-Multazam), 4(1), 43-51.

Siregar, P. S., Wardani, L., \& Hatika, R. G. (2017). Penerapan Pendekatan Pembelajaran Aktif Inovatif Kreatif Efektif dan Menyenangkan (Paikem) pada Pembelajaran Matematika Kelas IV SD Negeri 010 Rambah. Jurnal Pemikiran dan Pengembangan Sekolah Dasar (Jp2sd), 5(2), 743-749. 
Volume 7 Nomor 3 Tahun 2019

Sugiyono. (2015). Metode Penelitian Pendidikan: Pendekatan Kuantitatif, Kualitatif, Dan $R \& D$. Bandung: Alfabeta.

Wahyudi. (2015). Panduan Pembelajaran Matematika Sekolah Dasar. Surakarta: UPT. Penerbitan dan Percetakan UNS. 